Check for updates

New York

Cite this as: $B M J 2022 ; 376: 010$ http://dx.doi.org/10.1136/bmj.o10 Published: 05 January 2022

\title{
Covid-19: Military medics are sent to hardest hit hospitals as US records a million cases a day
}

\author{
Janice Hopkins Tanne
}

President Joe Biden has told Americans, “Be concerned about omicron, but don't be alarmed," after the United States recorded more than one million new cases on 3 January. ${ }^{12}$

Biden emphasised the importance of vaccination in a speech on 4 January. "If you're unvaccinated, you have some reason to be alarmed," he said. "Many of you will experience severe illness ... if you get covid 19 if you're not vaccinated. Some will die-needlessly."

He added, “There's still 35 million people not vaccinated. We have ... all the vaccines we need to get every American fully vaccinated, including the booster shot. This continues to be a pandemic of the unvaccinated."

He encouraged parents to get their children vaccinated or, if they were too young to be vaccinated (under 5), to "surround your kids with people who are vaccinated. And make sure you're masking in public so you don't get covid and give it to your kids.”

\section{Free tests}

Biden said that the federal government had deployed hundreds of military doctors and nurses to staff hospitals in states that were overwhelmed with unvaccinated patients. The government was also ready to provide emergency hospital beds if needed, he said, and had already shipped nearly 2.4 million pieces of personal protective equipment to hospitals.

He emphasised that booster shots were available free of charge at more than 90 ooo vaccination sites. He added that testing was being improved with a website for locating test sites. Many states, local governments, and healthcare providers were also handing out free home tests. The federal government will launch a website this month where people can get tests shipped to their homes free.

For people who are at high risk if they become ill, Biden said that a new Pfizer pill, Paxlovid, greatly reduced the risk of hospital admission and death. "Production is in full swing," he said. "The United States has more pills than any country in the world, and our supply is going to ramp up over the coming months as more of these pills are being manufactured. Today I'm directing our team to work with Pfizer to double our order from 10 million to 20 million treatment courses." He called the pills "a game changer" to alter the impact of covid-19.

The record high number of cases in the US may be partly a result of delayed reporting of cases that occurred over the holiday weekend. However, in the past week the number of cases has increased by $110 \%$ to a daily average of more than 487 ooo cases, the Washington Post reported. ${ }^{3}$ The number may be even higher because it does not include results from people who test at home and do not report the results. While hospital admissions have been increasing, deaths from covid-19 have fallen.

\section{Vaccination rates}

All 50 states, as well as Washington, DC, and Puerto Rico, have $300 \%$ of the cases they saw in January 2021. ${ }^{4}$ The current test positivity rate is $26 \%$ nationally.

The rise in infections has led to staff shortages at hospitals, airlines, police forces, and public transport systems-leading, for example, to thousands of flight cancellations over the New Year weekend and the closing of several subway lines in New York City. Most school systems are opening after the holiday break, including New York's-the nation's largest, with more than a million pupils. Other large cities such as Cleveland, Atlanta, and Newark have returned to online learning.

Maryland's governor, Larry Hogan, declared a state of emergency because cases were overwhelming hospitals. Texas's governor, Greg Abbott, said that he would not reconsider his ban on mandates for mask wearing. ${ }^{5}$

About $62 \%$ (206 million) of the US's population of about 330 million have been fully vaccinated, and $88 \%$ of people over 65 have been fully vaccinated. Vaccinations have been approved for children aged 5 and above but have lagged behind adult vaccinations.

On 4 January the Centers for Disease Control and Prevention said that moderately or severely compromised children aged 5-11 should receive an additional primary dose of the Pfizer-BioNTech vaccine 28 days after receiving their second shot. The Food and Drug Administration is reviewing a booster for children aged $12-15{ }^{6}$

The Centers for Disease Control and Prevention said that people could receive a booster vaccine five months (rather than six) after receiving their two dose Pfizer-BioNTech vaccine. The interval for people who received the Johnson \& Johnson or Moderna vaccine was not changed.

WhiteHouse.gov. Remarks by President Biden before meeting on covid-19. 4 Jan 2022. https://www.whitehouse.gov/briefing-room/speeches-remarks/2022/01/04/remarks-by-president-biden-before-meeting-on-covid19/

2 Johns Hopkins Coronavirus Resource Center. Tracking home. 4 Jan 2022. https://coronavirus.jhu.edu/data/cumulative-cases

3 Tracking US covid-19 cases, deaths and other metrics by state. Washington Post2022 Jan 4. https://www.washingtonpost.com/graphics/2020/national/coronavirus-us-cases-deaths/?state=US

Coronavirus in the US. Latest map and case count. New York Times 2022 Jan 4. https://www.nytimes.com/interactive/2021/us/covid-cases.html 
5 Nirappil F. Southeast US poised for a firestorm of omicron cases, with few safeguards in place. Washington Post2022 Jan 2. https://www.msn.com/en-us/news/us/southeast-us-poised-for-afirestorm-of-omicron-cases-with-few-safeguards-in-place/ar-AASmFKE

6 Centers for Disease Control and Prevention. CDC recommends Pfizer booster at 5 months, additional primary dose for certain immunocompromised children: media statement. 4 Jan 2022. https://www.cdc.gov/media/releases/2022/s0104-Pfizer-Booster.html

This article is made freely available for personal use in accordance with BMJ's website terms and conditions for the duration of the covid-19 pandemic or until otherwise determined by BMJ. You may download and print the article for any lawful, non-commercial purpose (including text and data mining) provided that all copyright notices and trade marks are retained. 